\title{
Reassessing attachment theory in child welfare
}

\author{
Sue White, Matthew Gibson, David Wastell \& Patricia Walsh \\ Policy Press, Great Britain, 2020 \\ ISBN 978 1447336921, pp.152, paperback NZD64.70
}

In 2019 Newsroom published a story showing the attempted removal of a newly born Māori baby by Oranga Tamariki (Reid, 2019). This story was met with outrage by many in the community (especially Māori: Sumner \& Reid, 2020), has been the subject of many inquiries, and has been instrumental in a Waitangi Tribunal claim against the state for present and historical over-reaches in child protection policies against tamariki Māori. Attachment has been a key concept mentioned in many criticisms of how Oranga Tamariki handled this case, both in the sense of attachment as theory and the attachment that the child is un/able to form with parents and wider whānau ${ }^{\mathrm{i}}$.

In late 2020, Newsroom again investigated the practices of Oranga Tamariki (Murphy, 2020). This time, however, they questioned the return of Māori tamariki from Pākehā foster families, back to their Māori families (often wider whānau members). The claim was that, since the original 2019 story, Oranga Tamariki had reassessed all cases involving tamariki Māori and were in the process of attempting to reconnect these children with biological whānau. However, this time, the attachment concept and theory was part of the media story, with New Zealand based 'attachment trauma expert' (as introduced) Nicola Atwool commenting in both the original story and a subsequent column (Atwool, 2020). The argument presented by both Atwool and the Newsroom team was that these children had now developed strong relationships and attachments with new caregivers and that a disruption of this would be, and was, traumatic for the children.
These two linked news stories show that attachment theory can play a crucial role in decision making in such cases in Aotearoa New Zealand. The purpose of this book review is to discuss what this book and recent articles about attachment theory have to say about the place of this theory in social work itself. If such a concept is indeed part of critical decision making about whether a child can stay with its parents or not, then it behoves us as social workers to be mindful of how we can wield such a powerful tooland indeed whether we should. Attachment theory, therefore, as the title suggests, is worthy of reassessment.

In the preface to their book, the authors, Sue White, Matthew Gibson, David Wastell and Patricia Walsh, explain that attachment theory has become a very powerful, yet adaptable staple in the kit of child welfare social work. They note that the theory can help comfort social workers experiencing increasing demands for evidence-based work alongside more bureaucratic oversight and performance targets. They comment that this comfort is perhaps because it is more "likable" than other theories like psychoanalysis and behaviourism (p. ix). However, they also caution that because the theory has become so fluid, "it is difficult to overstate the soaring ascent of the persuasive collection of ideas that is attachment theory" (p. viii). Therefore, practitioners can use attachment to explain all manner of behaviours, often leaving parents, particularly mothers, in no-win positions. Critically they note that the book is not setting out to be a "straightforward critique of attachment theory; rather, it is an attempt 
to examine its effects on how the child welfare system 'thinks' about children and their needs" (p. x). Therefore, the book asks how attachment theory is deployed in social work to highlight specific ways of thinking about children and their parents and ignore others.

The book starts in Chapter One with an exploration of attachment theory history and covers what social work readers might initially think of as familiar ground: Bowlby and Ainsworth. However, unlike many more typical formulations of the history of attachment theory, White and colleagues clearly show where some of the tensions and disagreements in the initial framings of attachment were. They note the limitations of the "Strange Situation" experiment (it was not random, staged, and the population studied was non-clinical), and emphasise how, from the beginning, there was a focus on parental behaviour (versus environment or even temperament of the child), particularly that of the mother. They end the chapter by noting that three key things made the theory ideally placed as a flexible tool for social work: an invocation of biology (appeal of the "natural"), key founders seeming impervious to critique, and being uniquely interdisciplinary - allowing adherents to pick and choose from separate disciplines to avoid critique.

Building from the previous chapter, the authors explain in Chapter Two how the relationship with social work came to be. Perhaps somewhat controversially, they suggest that the theory has come to function as a "myth" (p. 23)—not meaning that it is untrue-instead (drawing from Barthes) they suggest that it serves as a means of justification, a way of normalising and moralising. Indeed, recent work by Bjerre et al. (2021) evidenced the moralising function of attachment theory in social work case discussions where they observed that it had become less about using scientific concepts (although this is the surface-level justification) and more about temporal and cultural expectations of parenting.
This moralising dovetails with concerns in this chapter that the theory has become a normative tool; a way in which social workers and policymakers have utilised what seems like science to bring parents into line with middle-class parenting norms. They further caution that there has been a rapid dilution of the science of attachment theory in popular media and even "handbooks" into a "black box"' packaging that has neatly hidden any questions or controversies (p. 37).

Chapter Three focuses on how attachment theory shapes practice and interventions in the current political and social climate and, while it does not explore direct practice, it is perhaps one of the more critical chapters for it telescopes out to the macro view. There is a particularly interesting section on how the Harvard Center on the Developing Child contracted a public relations company to translate the science into more publicfriendly terms. For example, they note that the phrase "toxic stress" results from this collaboration, and is not a term grounded in original research. They go on to explain how, in recent times, attachment has become more and more biologised and note, like previous publications exploring similar (see Gillies et al., 2017; Wastell \& White, 2017), there has been enthusiastic uptake by proponents of attachment theory of ideas linking it to neuroscience and epigenetics. Therefore, attachment theory is being coupled with these emergent, biologising ideas to further galvanise action for increasingly early interventions in child protection.

After the previous chapter's macro view, Chapter Four discusses how attachment theory is deployed in practice. They note that the reliance on attachment theory in social work can be linked to a desire for professionalisation. When reading this, I noted an affinity with Flexner's long ago but oft-cited declaration (2001, [1915]) that social work needed its own distinct knowledge base to be considered worthy of the designation profession. Therefore, the authors suggest that social work and social 
workers are still feeling this threat today and are thus using attachment theory as an answer to this need. Referencing several studies from different countries (including Aotearoa New Zealand) the authors show that social workers are indeed using the theory in this way-both consciously and unconsciously. Referencing their suggestion from the preface that social workers use attachment theory in a comforting way, to back themselves with a theory, they caution that such use means that it has rapidly become a common sense concept which is thus far less open to critical thinking and challenge. They conclude that this push for social workers to gain "authority and power has resulted in the 'black boxing' of the complexities and contradictions of the theory" (p. 81).

Chapter Five focuses on the use of disorganised attachment in child protection whereby they note that for many, such a designation for a child has become shorthand for child maltreatment. Referencing an extensive review of the concept (see Granqvist et al., 2017) they trouble the notion that the evidence base on disorganised attachment is straightforward, even organised, and strongly caution against such use in practice.

In Chapter Six, the authors return more extensively to the biological turn in recent attachment theory research and spend some time discussing the problems using such analysis (which predominantly uses rodents as proxies for parents-primarily mothers). It is here that readers interested in the studies of rat mothers who did and did not lick and groom their babies, and then the resultant parental behaviour of these pups (see Meaney, 2001), will find an insightful and critical analysis of how these observations were generated. They go on to note that such research, aside from leading to gendered and classed assumptions, seems to make attachment, and even love, a far more delicate and fragile thing, indeed, "it has grown spikes that press into your cells and make you sick" (p. 120).
Their final section, 'Coda: Love reawakened?' notes that all is not lost for attachment theory. Like the authors of a recent article on the use of attachment theory in child protection and custody cases (Forslund et al., 2021), they state that attachment theory is best applied when not using it to assess individual differences and when it is used to focus (ethically) on relationships: "it provides a way of thinking with the family about their relationships" (p. 133). They emphasise that (like many other psy-theories) attachment theory is a product of its time and was created in a specific cultural and temporal moment that reified white, Western values (something also pointed out by Choate et al., 2020) and, as such, social workers and policymakers need to exercise far more caution in using and relying upon it. They end the book on a hopeful note and explain that, as attachment theory was (historically) influenced by social work, perhaps now social work can again exert influence back on attachment theory to render it more appropriate in multiple contexts.

It would be tempting to read this book as overly critical of attachment theory, focusing on the contradictions in its history, use and application, and the comfort that many social workers feel in using this theory. However, that view would be far too simplistic, and one would risk residing too much in the somewhat uncontested space that attachment theory has in the social work world - a space that the authors try very hard to push us out of. It is precisely the existence of that comforting uncontested space that should prick our conscience into delving further. This sort of delving is especially critical in a bicultural Aotearoa New Zealand where the uncritical application of any imported theory should raise eyebrows, especially those of any social worker whether they be a student or an experienced practitioner.

Perhaps then in thinking about the stories that I opened this review with, two cases that both relied (in different ways) on attachment theory, and both involving Māori children, 
we as social workers based in Aotearoa New Zealand (or in any colonised nation) need to rethink whether this tool, attachment theory, is fit for purpose. Is attachment theory something that can be salvaged? Are we as social workers ready to question something that many of us have held dear? Can we put down the tools and start again? In asking these questions, I am reminded that "the master's tools will never dismantle the master's house" (Lorde, 2003, p. 27). If attachment theory is embued with western thinking, and does idealise white middle-class parenting, and is involved with creating the house of child protection that we see today, as is suggested by this book, then surely we do need to put the tools down and ask ourselves these questions as a matter of urgency.

\section{Note}

For example, in the Oranga Tamariki internal review it was noted that consideration for attachment needed to be made in planning for uplifts (Review oversight group, 2019), and the importance of attachment was stressed repeatedly in both recent reports on Oranga Tamariki from the Children's Commissioner (Office of the Children's Commissioner, 2020a; 2020b).

\section{References}

Atwool, N. (2020, November 27). The collateral damage of ideologically-driven uplifts. Newsroom.co.nz. https:// www.newsroom.co.nz/investigations/ideologically-drivenuplifts

Bjerre, L. S., Madsen, O. J., \& Petersen, A. (2021). 'But what are we doing to that baby?' Attachment, psy-speak and designed order in social work. European Journal of Social Work, 1-12. doi:10.1080/13691457.2020.1870439

Choate, P. W., CrazyBull, B., Lindstrom, D., \& Lindstrom, G. (2020). Where do we go from here? Ongoing colonialism from attachment theory. Aotearoa New Zealand Social Work, 32(1), 32-44.

Flexner, A. (2001). Is social work a profession? Research on Social Work Practice, 11(2), 152-165. doi:10.1177/104973150101100202 (Originally published 1915).

Forslund, T., Granqvist, P., van IJzendoorn, M. H., SagiSchwartz, A., Glaser, D., Steele, M., .. . Duschinsky, R. (2021). Attachment goes to court: Child protection and custody issues. Attachment \& Human Development, 1-52. doi:10.1080/14616734.2020.1840762

Gillies, V., Edwards, R., \& Horsley, N. (2017). Challenging the politics of early intervention: Who's "saving" children and why. Policy Press.

Granqvist, P., Sroufe, L. A., Dozier, M., Hesse, E., Steele, M., van ljzendoorn, M., . . . Duschinsky, R. (2017). Disorganised attachment in infancy: A review of the phenomenon and its implications for clinicians and policymakers. Attachment \& Human Development, 19(6), 534-558.

Lorde, A. (2003). The master's tools will never dismantle the master's house. In R. Lewis, \& S. Mills (Eds.), Feminist postcolonial theory: $A$ reader (pp. 25-28). Routledge.

Meaney, M. J. (2001). Maternal care, gene expression, and the transmission of individual differences in stress reactivity across generations. Annual Review of Neuroscience, 24(1), 1161-1192.

Murphy, T. (2020, November 27). Court orders newsroom to remove Oranga Tamariki video. Newsroom.co.nz. https://www.newsroom.co.nz/investigations/crown-askscourt-to-remove-newsroom-video

Office of the Children's Commissioner. (2020a). Te kuku O te manawa-moe ararā! haumanutia ngā moemoeā a ngā tūpuna mō te oranga ngā tamariki. Author. https://www. occ.org.nz/publications/reports/tktm-report-2/

Office of the Children's Commissioner. (2020b). Te kuku o te manawa: Ka puta te riri, ka memorie te ngākau, ka hele ngā roimata mo tōku pēpi. Author. https://www.occ.org. nz/publications/reports/te-kuku-o-te-manawa/

Reid, M. (2019, June 11,). NZ's own "taken generation". Newsroom.co.nz. https://www.newsroom.co.nz/ investigations/nzs-own-taken-generation

Review oversight group. (2019). Practice review: Professional practice group practice review into the Hastings case. New Zealand Government.

Sumner, B., \& Reid, M. (2020, July 2). Māori leaders repeat calls for OT resignations. Newsroom.co.nz. https:// www.newsroom.co.nz/mori-leaders-repeat-call-for-otresignations

Wastell, D., \& White, S. (2017). Blinded by science: The social implications of epigenetics and neuroscience. Policy Press.

Reviewed by Eileen Joy Registered social worker and $\mathrm{PhD}$ candidate 